ANNA AUgUSTYN - GUSZTÁV NEMES ${ }^{1}$

SOCIAL COMPONENTS OF FOOD MARKETING IN RDP-SUPPORTED PROJECTS

DOI: $10.18030 /$ SOCIO.HU.2016EN.218

ABSTRACT

In response to a growing awareness of the consumers across Europe, efforts towards improvements of food marketing have been intensifying during the last decades. Targeted actions to tackle these challenges have been undertaken by rural communities, public and private sector, including large multi-national companies. This paper looks at the various approaches fostered within the EU Rural Development Programmes. We review different types of marketing schemes relevant for EU rural areas, affected by both market and public sector mechanisms. Social components have been frequently added to these, based on voluntary, bottom-up processes and quality control, and embedded in local community and economic development. We claim that social marketing can be effectively combined with the public support available under the EU rural development policy and help food producers to gain better access to markets. The value that social networking and bottomup rural development represent in the marketing of local products is essential for food-driven innovation in rural areas. Our paper presents an analysis of projects from the database of the European Network for Rural Development, clustered around different social marketing components.

Key words: social marketing, rural development, Common Agricultural Policy, standards

1 Anna Augustyn is an independent consultant, and co-chair of Groupe de Bruges. Gusztáv Nemes is research fellow at the Hungarian Academy of Sciences, Institute of Economics and lecturer at the Budapest Corvinus University. 


\section{SOCIAL COMPONENTS OF FOOD MARKETING IN RDP-SUPPORTED PROJECTS}

\section{INTRODUCTION}

Food belongs to the strategic concerns of the EU Common Agricultural Policy (CAP). It has been broadly recognised as an important factor for successful rural development (Tregear 1998, Marsden 2000, Renting et al. 2003). Introduced in 1962 as a response to the post-WWII scarcity and austerity, nowadays the CAP combines a set of instruments and tools addressing food-related issues. They offer a systemic response to many specific problems connected to food production, such as health and safety, complex developments of the market, the sustainability of rural communities, production methods, phytosanitary, animal welfare, or labelling and quality control.

This study offers an insight into those CAP instruments that facilitate and finance food marketing under the 'second pillar', that is the so-called Rural Development Regulation (Council Regulation (EC) No. 1698/2005). We concentrate on the results achieved during the 2007-2013 programming period, using the available data related to the delivery of specific measures supporting food production and marketing. The broader context of the theoretical narratives and practical evidence during the realisation of the EU RDPs helps to navigate through the challenges and complexity of food value chains. At the same time, the importance of social networks and local participation in triggering innovative food marketing strategies, and consequently the development of rural communities, can certainly be detected.

Observing the Rural Development Programmes (RDPs) 2007-2013, one can notice the growing importance of the 'social' component, supporting cooperation, networking or peer-to-peer learning among others. In this paper we pull together these approaches under the common term of social marketing of food and interpret them in the specific context of EU public policy support. Our context is a neo-endogenous rural development approach, based on social innovation and strategic planning (Ray 1998, Shucksmith 2010). In addition, social marketing has strong roots in organisational and marketing theories (Kotler-Zaltman 1971, LefebvreFlora 1988, Kotler-Roberto 1989, Andreasen 1994, Kotler et al. 2002). It is affected by commercial marketing methods and at the same time means a public intervention aimed at the change of social behaviour. Some important RDP measures, relying on social processes and various forms of engagement between producers and consumers ultimately aim to raise profitability for food chain actors. Social marketing of food, at the same time, brings together local producers and products in order to reach consumers directly and offer them special, high value added, processed food products. Policy measures, thus, can make an important contribution to the perception and choices of consumers reinforcing local, traditional products against mass produced food available in supermarkets. 


\section{RESEARCH METHODOLOGY}

Drawing on academic literature and EU regulatory documents we situate our survey in a specific narrative of global developments affecting the European agro-food system. Local perspectives, through examples of RDP projects, provide complementary and contesting views. Based on the grounded theory approach (GlaserStrauss 1967), our empirical work is mainly based on the secondary content analysis of food related project examples included in the RDP projects database of the European Network for Rural Development (ENRD) ${ }^{2}$. We first clustered RDP projects according to the criteria of indicating social marketing components. Then, the descriptions of food-related projects in the ENRD database were screened in detail, in order to extract those components indicating the engagement with the society as an element of product marketing approach. Observing the meaningful patterns, we provide a statistical overview. We also highlight examples of particular projects, supplementing the ENRD database with more qualitative information (publications, websites, videos) enabling us to gain deeper insights into their implementation. Consequently, we analyse the results with a view to provide possible answers to the following questions: Which RDP instruments are most favourable for fostering social food marketing? What are the main characteristics of the related RDP projects? What is the added value of social marketing in this context? This way, we intend to provide a meaningful operationalisation of the social marketing concept.

\section{THE ENGINES OF FOOD MARKETING: STANDARDS, CERTIFICATION AND QUALIFICATION SCHEMES}

Traditionally, the European agro-food system was dominated by the 'family farm' as a central unit of socio-economic organisation. People used to produce, process and eat local food, and rely on solidarity and help of others in their close neighbourhood. Very few products travelled far, and these were luxury ingredients, normally not present in the every-day diet of average families. This kind of society was greatly based on self-consumption (Fonte 2002) and 'local food' had a very concrete and simple meaning, since most food was normally produced in a surrounding geographic area. However, the evolution of food production and supply chains gained pace with the industrial revolution, changing geo-political regimes, increasing migrations and rapid population growth. Fundamental changes further sped up in Europe from the 1960's, following the launch of the CAP. The modern agro-industrial system gradually replaced traditional production methods, and family farms. Under the new order, crowds of people moved to cities, food started to be mass-produced, often losing quality and connection with its origin too. Thus, 'local food' virtually lost its meaning. Traditional ways of food production had to change; industrial agricultural farms did not produce for self-consumption any more. Urban firms began to dominate the organisation of food value chains. Supermarkets, where both city dwellers and most rural people did their shopping, sold products from anywhere and everywhere, consumers became disconnected from production and unable to trace and control its details.

With the arrival of the 'new rural paradigm', however, the industrial agro-food system became somewhat discredited for generating poverty, exclusion and pollution rather than welfare and social progress (Lowe

2 European Network for Rural Development, Rural Development Programmes' projects databasehttp://enrd.ec.europa.eu/enrdstatic/policy-in-action/rdp_view/en/view_projects_en.html [last accessed July 2015]. 
et al. 1995, Bryden 2004, OECD 2006). Public concerns about hygiene, mass diseases, pollution, animal welfare, changing lifestyles and consumption patterns finally gave raise to new regulatory frameworks controlling food production in every detail. Decrees, institutions and policies intended to provide (EU) citizens with standards that could guarantee the quality, hygiene and traceability of their food. While in the past this sphere was mainly regulated by the public authorities, nowadays it has gradually been shifting out of the public domain. Multiple actors became interested and engaged into regulatory efforts towards setting up food standards, such as private market players and civil society organisations. This led to the development of third party certifications (Hatanaka et al. 2005) and tripartite regimes governing quality assurance, labelling and branding systems (Busch 2010, Loconto-Busch 2010) for food products. Specific governance mechanisms emerged, which are expressed through dedicated institutions and networks, at various territorial levels and across the agro-food sector. Their role is to deal with the creation and 'enforcement' of standards, for instance through audits and controls.

During recent decades the development of information and communication technologies (ICTS) have radically shifted the understanding of space and time, putting more emphasis on the networked character of society (Castells 1996). In parallel, the increasing globalisation of food value chains contributed to a growing complexity of relations between producers and consumers. A new kind of 'local consumer' emerged, living mostly in urban areas (Marescotti 2000), but caring very much where their food comes from and how it is manufactured. In developed countries the relationship between producers and consumers was thus widely revisited. Social movements and alternative food networks (AFNs) took off, formed by customers searching direct personal relationship with their food, its origin and its producers (Cooley 1998, Cone-Myhre 2000, Marsden 2000 et al., Renting et al. 2003, Goodman 2004, Friedman 2005, Guthman 2008). The alternative food networks advocate face-to-face contacts, spatial proximity and spatial extension, though the majority of consumers reside outside the rural area where the food is actually produced. All this brought around new forms of marketing (e.g. box schemes, producers' markets, farm shops, agro-tourism), institutions (e.g. customer groups, consumers' co-operatives), different ways of community supported agriculture and other 'slow food' trends. Some people started to produce their own food again in city allotments, urban gardens or moving to the countryside. Others buy 'local food' in the centre of large cities, on farmers' markets or are part of community supported agriculture (CSA) groups.

The trend is so strong that even large supermarket chains could not avoid it and nowadays one can find 'local food sections' and brands labelled as 'local', 'traditional', 'artisanal' or 'organic' in many of them. All this could be seen as a renaissance of the 'local food', attributing new connotations to the near forgotten term. In this sense 'local food' means that we know: (1) where our food is from, (2) it is produced on a small scale and (3) in a 'friendly way', (4) it is good quality (safe and tasty) and (5) we can have some kind of direct personal attachment to its production and producers. This logic has been followed by many territorially based regional schemes employed for qualification, certification, and defining standards of production and supply in Europe and around the world. Rural strategies started to treat local or regional food as a beneficial component for socio-economic development, however, its explicit impacts are rather difficult to measure (Tregear et al. 2007). 
The incumbent European regime, while still financing industrial food production on a grand scale, also started to mitigate the negative socio-economic effects, supporting alternative initiatives concerned with health, safety and traceability, aimed at both social and commercial objectives (Tregear et al. 1998). Ray (1998) notes that local food products are strongly rooted in the symbolism of social movements, such as emerging networks under the EU LEADER Programme. Typical local/regional good quality food products play an important role in rural development (Pacciani et al. 2001). Food quality is, however, a contested idea. It emerges in the process of negotiations between actors, establishing common procedures and standards, creating a fertile ground for the development of certification and branding schemes. The demand for ensuring quality implicates a number of actors alongside the food chain, from producers to consumers. Labels based on standards and qualification schemes are prominent in food marketing strategies (Ilbery-Kneafsey 1999, Marescotti 2000).

The industrialisation of the agro-food system did not diminish traditional ways of production completely. In recent years small-scale farming encountered a revival in many developed countries and was broadly promoted by the key international public players (such as for instance FAO or the European Commission). At the same time, however, smallholders face challenges in the 'global market' and are at continuous risk, having a rather limited ability to participate even in the markets within their geographical proximity. A number of studies attempted to explore the impacts of food standards and their trade-offs for small producers. According to some (Ilberry-Kneafsey 1999, Loconto-Dankers 2014, and others), standards, set up by large players of the value chain endanger small-scale farmers and food processors. Evidence suggests that compliance with standards can significantly increase the costs of production, but does not necessarily result in improved quality, nor does it automatically lead to an increased profit for small food producers. However, it is also apparent that participation of small producers in the development and application of standards normally results in improvements in their capacity to participate in the certified markets through affiliation with dedicated groups or networks. In addition, some targeted public support or mixed public-private approaches can normally be very helpful (ibid.).

\section{SETTING UP FOOD STANDARDS WITHIN THE CAP: TOWARDS THE SOCIAL MARKETING OF FOOD}

The main practices of food standardisation under the CAP are associated with quality support, certifications and labelling. Most notable schemes are within the EEC Regulation 2081/92 - Protected Designations of Origin (PDOs), Protected Geographical Indications (PGIs) and Traditional Specialties Guaranteed (TSG). They offer dedicated instruments targeting territorial characteristics, quality and specifics of food products (CEC, 1992). Until July 2015, some 1285 products indications have been registered under these geographic indications, and many are currently in the process of application (DOOR Database). In addition, an EU label indicating organic farming practices can be acquired by food producers (Council Regulation (EC) No. 834/2007).

The main aim of these schemes is to support good quality, culturally rooted products, through providing them with some competitive advantages on the market. This also allows removing the barriers created by the basic principles of equal opportunities and free movements of goods within the EU. These standards are public and their uptake depends on voluntary decisions of producers. Over time, they have resulted in a growing popularity and recognition among consumers. Products with related labels can be found in many shops across 
Europe, both big-chain supermarkets and more specialised local retailers or food markets. Beyond a marketing advantage, another possible benefit of these labels is that the geographic indication helps to guarantee exemptions of specific products from the strict HACCP standards that food producers have to comply with in the EU.

The impacts of geographic indications have been studied in detail, using diversified methodologies and tools (Barjolle et al. 2009). Also, they tend to be much dependent on the context. For instance, according Pacciani et al. (2011) this is related with the different strategies to valuate typical food products to acquire PDO / PGI certifications. They are driven by numerous actors and processes, such as food producers, local authorities and retailers. They perceive typical products as certain assets, both material (e.g. specific plant breeds) and immaterial (e.g. knowledge of local agents), whereby the quality of products is derived from these and associated with a specific area. The valorisation strategies have thus both economic and socio-cultural dimensions. The acquisition of PDO/PGI often raises conflicts between different actors and interests as it affects their participation in or exclusion from the markets. They also lead to an increasing commodification of local assets. Although, reverse examples can also be found, where the certification process leads to enhanced local collaboration and increased awareness of the communities how a food-based strategy can benefit territorial development (ibid; Tregear et al. 1998).

The process of getting the EU geographic indication often involves 'collective value creation' (BarjolleSylvander 2002). Due to the highly competitive and exclusive nature of these schemes, their conditions are often difficult to meet by smallholder farmers and local communities. A degree of social capital and many other capacities are needed, in order to participate in the schemes and realise successful rural development (Tregear et al. 2007). However, many rural communities lack such capital or capacity. There is a significant gap in the 'official marketing support system', leaving out a large number of small producers, exactly those players who would particularly need help and assistance both in the raising and control of quality and in the marketing of their products. Thus, marginalised rural communities may encounter difficulties on the way to acquiring the EU geographic indications. One of the main challenges is the difference between 'long established and valuable specialties', which have already gained a certain reputation, and those that are 'nascent or developing systems' (Gorton et al. 2014). Therefore, the access of smallholder farmers and food producers to these schemes should be enabled with suitable policy instruments. These can for instance be found in RDPs and we describe some examples later in this paper.

Marescotti (2003) notices that local communities actively estimate the trade-offs of participation in geographic indication schemes, especially the increased costs of production. The refusal of participation in these schemes is quite typical for those products that are embedded in short value chains, sold near the place of production, mainly to local consumers and tourists. In this case, geographical proximity and the personal involvement of producers can substitute for a certified label. However, this drives us back to the fundamental question that producers and local communities in general have to answer: whether they want to bring customers to their own locality and sell their products directly, or if they want to expand their businesses to reach the 'big markets'. In the first case the food marketing process serves as an 'extended territorial strategy' and contributes to a wide range of initiatives encouraging diverse activities and novel interactions between multi- 
ple types of actors. In the second case the branding process serves as a 'supply chain strategy' (Pacciani et al. 2001), enhancing a strong producer network, the effective management of the supply chain and the (mainly external) marketing of the products.

Social marketing can be supported with specific policy measures and campaigns (Michaelis-Lorek 2004, Reisch et al. 2013). In the context of RDP, we suggest to understand it as a hybrid system, combining public support available under the EU rural development policy with resources of the private sector and assets of local communities. It aims at a harmonic inclusive and sustainable development of local economies and societies. Social marketing is often initiated by some kind of local reflexive agency (sensu Nemes et al. 2014), such as an animation unit of the LEADER Local Action Group, and strongly involves entrepreneurs and service providers from the outset. The definition, certification and control of quality is based on local participation and embedded social processes. It aims both at bringing external customers to the locality and exporting local products to external markets. It intends to sell not only products, but also the 'experience' and the 'image', thus the whole locality. It is either a territorial brand including many different products and services, or it refers to some kind of production method that is widespread and accessible for many in a certain locality. Moreover, social learning and social innovation processes (sensu High-Nemes 2007, Knickel et al. 2009, Bock 2013) are crucial for the social marketing schemes.

\section{Food MARKeting Strategies fostered by the RuRal DeVelopment Programmes}

Although the majority of CAP funding is still dedicated to the support of larger farms and industrial agriculture, systematic changes to assist smallholders are already visible in a number of national and regional rural development programmes. Alongside the 'classic' CAP certification schemes, specific additional incentives for setting up voluntary food standards are offered, creating the space needed for marketing experiments and innovation in this field. Several measures propose alternative solutions for smallholder farmers and food entrepreneurs to address the gaps that the above described 'official standards' leave in the system. Thus, during the 2007-2013 programming period various RDP instruments contributed to 'local standardisation' and the development or enhancement of food brands. The EU Member States could choose from a menu of measures offered under the four axes of the CAP RDR to create specific policies fitting their particular contexts. Hence, CAP implementation varied by country and was strongly reliant on individual projects realised by farmers, food producers and processors, retailers, Local Action Groups etc. Implemented measures could refer to many different areas, but food related issues normally represented an important target. By studying examples of the implemented projects, we detected certain social marketing strategies. We describe them in the following sections in detail.

\section{THE ENRD DATABASE: FOOD PROJECTS}

Our main source of information was the database of the European Network for Rural Development (ENRD), containing best practice examples of rural development projects supported by RDR across the EU. The database was generated through the collection of projects during the implementation period of the RDPs 
Figure 1 Overview of the food projects in the ENRD database by measure

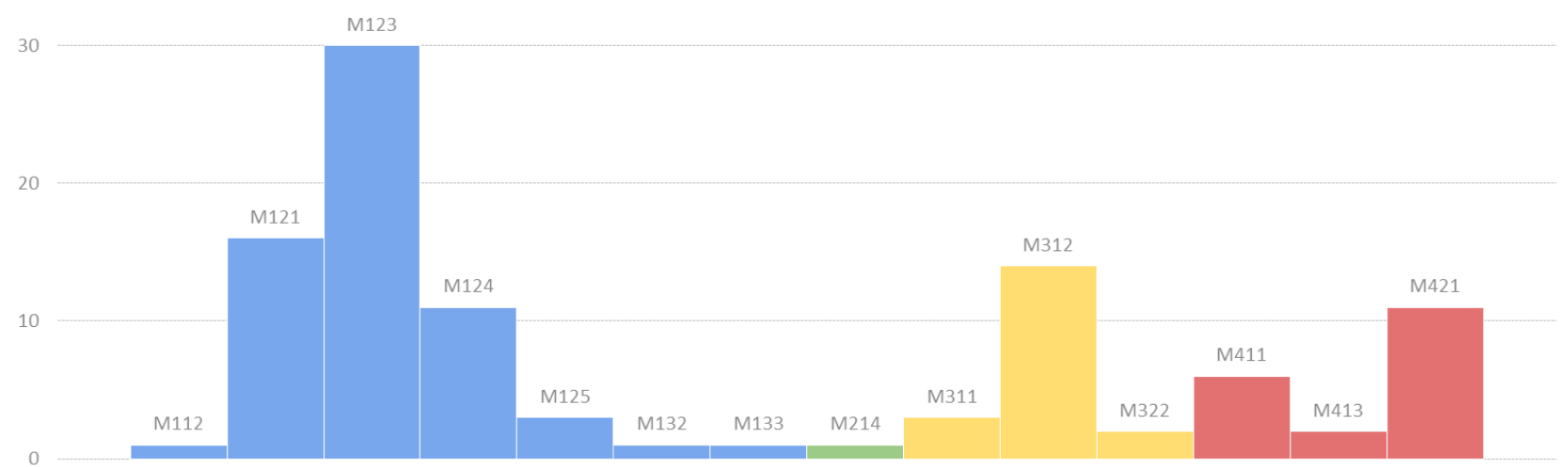

Source: Calculations of the authors

2007-2013, following the specific needs of the ENRD. ${ }^{1}$ The actual sets of measures and the speed of their implementation were unique in each EU Member State/region (in the case of the regional RDPs). Also, the database was developed gradually, over several years and concentrating on different topics in different periods, the information available was varying over time. As a consequence, the database cannot be seen as fully representative concerning all the projects implemented under the RDPs in the whole EU and conclusions based solely on these data are still of limited merit. Nevertheless, there is no better source at the moment and the ENRD database certainly gives a pretty good indication of the general development trends and points of interest for further investigation of food-related projects. In some cases, the database is supported with complementary material, such as files, pictures, links to websites and videos, from which we were able to learn more details about the projects.

In total, the ENRD database contains 641 individual project descriptions (state as of July 2015). An advanced search, using 'food' as a filter, highlights 107 projects, representing some $17 \%$ of the total. This suggests that food-related projects were getting substantial attention in the RDPs 2007-2013. Figure 1 illustrates how the financial support to food-related projects was shared between different RDP measures presented in the database. Below we cluster them according to the specific criteria and undertake a detailed analysis.

Overall, the support to food related projects was the most visible under the axis 1 (competitiveness of agricultural and forestry sector) measures and embraced nearly a half of them (53 out of 107 projects). This might be also less surprising, if keeping in mind that in many EU Member States, axis 1 was the most 'fuelled' in budgetary terms. On the contrary, axis 2 (agro-environment) food-related projects remained rather marginal, despite a similarly strong financial capacity. Nevertheless, through the design of individual measures, this axis did not focus directly on food projects. In addition, some 19 food projects were realised in both axes 3 (quality of life and economic diversification) and 4 (LEADER).

According to the database, the highest number of food projects (30) were realised under the M123, focusing on 'adding value to agricultural and forestry products'. With 16 documented cases 'farm modernisation

1 One of the authors of this paper was personally involved in the development of the database, but opinions expressed in this paper do not represent the official position of the ENRD. 
and investments' took second place (M121). Also, 11 projects targeting 'cooperation for development of new products, processes and technologies in the agricultural and food sector' (M124) offer significant insights. It is quite surprising that only 1 project was recorded that is directly focused on 'supporting farmers who participate in the food quality schemes' (M132), which means that it was either less prioritised in the ENRD work or that the delivery of the measure was not well advanced at the time. Other relevant measures were found under axis 3. These are 14 projects under M312 'support to the creation and development of micro-enterprises'; and axis 4 LEADER (11 projects under M421, 'transnational and interregional cooperation', and 6 projects under M411, competitiveness). In some countries or regions LEADER was a mainstreamed approach towards other RDP axes. This means that the food-related projects could have been implemented through this approach (and through the LAGs) in other axes than the fourth. However, we are not able to state this unambiguously in connection with the database, because this criterion is not clearly embedded there.

\section{TOWARDS THE SOCIAL MARKETING OF FOOD}

The next step in our survey, following the grounded approach, was the clustering and a detailed content analysis of the projects. The database contains brief information about the project objectives, activities, results and benefits, lessons learnt, involved partners and financial data. Within these descriptions we looked for indications of social engagement that could be traced in particular projects, regardless of the axis or measure they belonged to. We looked for repeating patterns, exploring the relevance of each dimension in the implementation of every project, and finally considered only those appearing in at least five different cases. As a result, the following typology of social marketing with six categories/dimensions was created:

1. Cooperation: the projects generated some forms of cooperation between food producers and/or processors, suppliers of raw material, retailers, information brokers (e.g. researchers, experts), local authorities or reflexive agencies (e.g. LAGs, cooperatives).

2. Joint marketing: the projects focused on common efforts towards identifying new marketing strategies and/or channels, including labelling, branding, joint sales efforts, developing printed and online marketing tools, participating in fairs or exhibitions together, etc.

3. Social events: these projects supported events, creating enhanced opportunities for interactions between producers, retailers, consumers, etc. (e.g. fairs, culinary routes, social dining etc.)

4. Social learning: the projects implied knowledge transfer and/or the creation and rediscovery of local knowledge aimed at individuals and/or communities in order to enhance production methods, product quality, marketing, etc.

5. Intercultural learning: the projects involved learning or knowledge transfer between different countries and cultures, e.g. through study visits.

6. Social space: the projects had an essential focus on investing into public space and built infrastructure where the products could be promoted, tasted and sold (e.g. farmers' market). 
Overall, our survey revealed that 34 projects out of 171 included at least one element of social marketing. These were found in 15 projects of axis 1 , in 5 projects of axis 3, and in 14 projects of axis 4 . None was detected in axis 2 projects. The most visible pattern from all the studied cases was cooperation in different forms. For instance in the axis 1 project 'Fio Dourado - a commitment to high quality olive oil' cooperation was fostered between the food processing industry and farmers supplying raw material. In other projects, marketing of food strengthened the mutual relationships between farmers, industry and scientific communities, in order to develop innovative products. In some cases cooperation was a basis of further application for geographic indications (e.g. in the Italian project 'A New Recipe for a High Value Potato Supply-Chain'). Transnational and inter-territorial cooperation was in turn the essence of social marketing strategies within the LEADER projects.

A well-documented example of transnational cooperation is the project 'Smak na Produkt' ('Taste of Product') implemented through the collaboration of one Austrian and seven Polish LAGs. At the heart of the approach was the knowledge transfer from an experienced 'old' EU Member State to a 'newcomer'. The partners organised a series of events to promote the idea of local food products in their respective communities. Participation of smallholder farmers and food producers in fairs and markets both in Poland and Austria was supported. Joint reflection about the development of product quality, a complex branding process and the improvement of overall food marketing strategies were also part of the project. A number of producers got involved in the project, many local products were promoted and finally some 15 of them acquired a traditional food label granted by the Polish public authorities at the Voivodship level. One of the products (Zatorski Carp) proceeded with application for European protection under the PDO scheme and established a strong market presence in Poland.

The second most frequent dimension, after co-operation was joint marketing, observed in 21 projects. The main activity here was bringing together small producers and food processors to create new brands or improve existing ones through more, or less sophisticated approaches. Joint marketing was often supported through social events ( 15 projects), where food producers could meet consumers and each other. A prominent example of this was a LEADER transnational cooperation project ('Connect Farmers' Markets along the Border'), reactivating traditional famers' markets in Italy and Slovenia. A survey was performed to identify the variety of local products and a number of joint events organised. They consequently led to development of a common geographic indication 'Zelen Kras' and enhancing public recognition of other products from the region.

Another important aspect of social marketing strategies was social learning (15 projects). This meant bringing project participants together, generating knowledge exchange about certain practices in relation to their food products. In some cases learning occurred among peers (e.g. farmer-to-farmer), while in others it involved the transfer of knowledge between different types of actors (e.g. scientists and farmers). Moreover, intercultural learning was a strong component in 12 projects, where knowledge was transferred across national borders. This was most frequently visible in LEADER transnational cooperation, but also in axis 1 and 3 projects, where entrepreneurs undertook study trips to visit their peers in other countries.

Six out of the explored 34 projects focused on developing some kind of infrastructure to allow product marketing and sales (social space), e.g. refurbishing an old building where social dinning events with theatre 
Figure 2. Number of RDP projects with identified social marketing dimensions

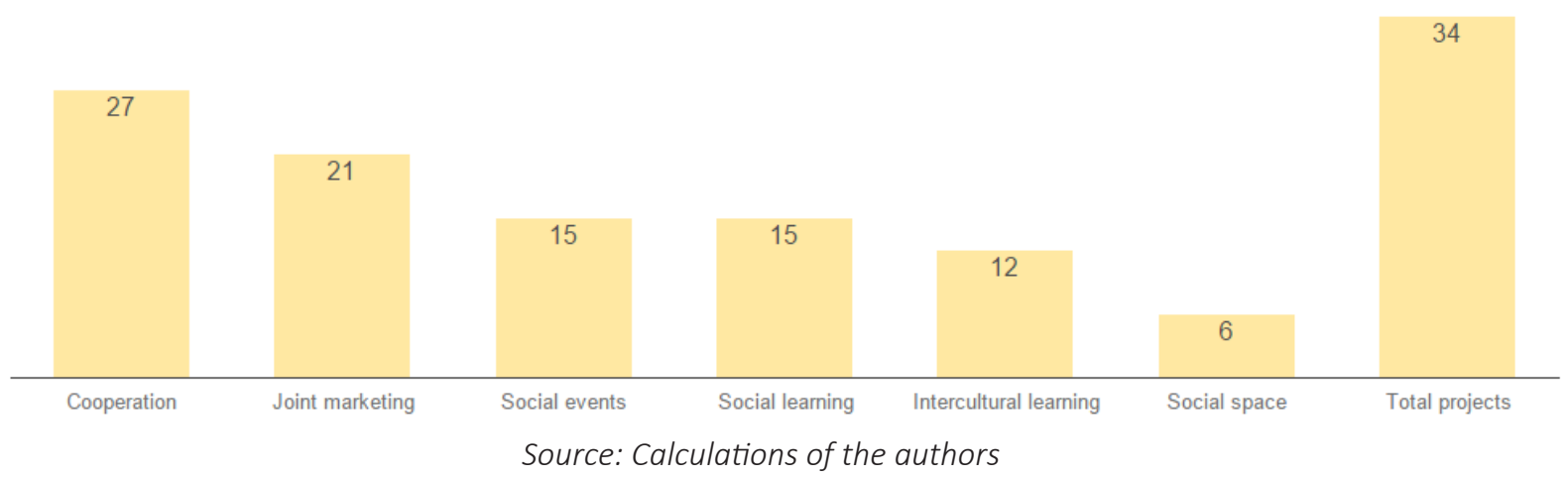

plays were organised (The Lerbäck Theatre Barn, axis 3). Other projects were devoted to construction of the physical space for farmers' markets, where the food could be offered regularly. Again, in other cases thematic trails were created with networks of objects facilitating tourists to meet local producers and purchase food directly. The figure below (Figure 2) presents an overview of the social marketing elements identified within 34 studied projects.

A more detailed exploration of the projects according to their social marketing dimensions in axes 1,3 and 4 brought further interesting results. In axis 2 we did not find any relevant projects as the only food related project identified did not demonstrate any of the social marketing dimensions. Overall, it became clear that only axis 4, that is the LEADER approach, had projects with relevant and significant connections to all 6 dimensions of the social marketing of food. In the case of axis 1, cooperation and joint marketing were notably involved, but other dimensions were barely visible, while in axis 3 they were marginal.

Our interpretation, of course, is limited, since the numbers of realised projects under each axis were different. The perspective of the primary focus of RDP measures concerned and their budgetary weights also resulted in different numbers of supported projects. Therefore, we decided to look at each individual project out of the 34 and check how many dimensions of social marketing it integrated. It turned out that on average LEADER axis projects had 4.8 components of social marketing. Five projects under this axis demonstrated all 6 dimensions, thus they were the nearest to our 'ideal type'. Moreover, the axis 4 projects were at least three-dimensional in every case. Second in this ranking proved to be axis 3 with 2.8 dimensions on average (1 minimum, 4 maximum). Axis 1, though represented with almost the same number of projects as axis 4 , was the least oriented towards social marketing with 1.6 dimensions on average (1 minimum, 3 maximum). Figure 3 below illustrates these findings.

In addition to the average, we measured the standard deviation and margins of error in each axis (Figure 4) to further justify our arguments. Due to the fact that error margins do not overlap, the comparison between axes 1 and 4 is more robust. We can state that numbers of social marketing dimensions in the projects under axis 1 were lower than those in the projects under axis 4 with more certainty. With regard to axis 3, however, the results need to be interpreted with caution and no ultimate conclusion should be drawn. The main limitation here is a very low number of projects that was studied (5). 
Figure 3. Minimum, maximum and average numbers of social marketing dimensions by axis

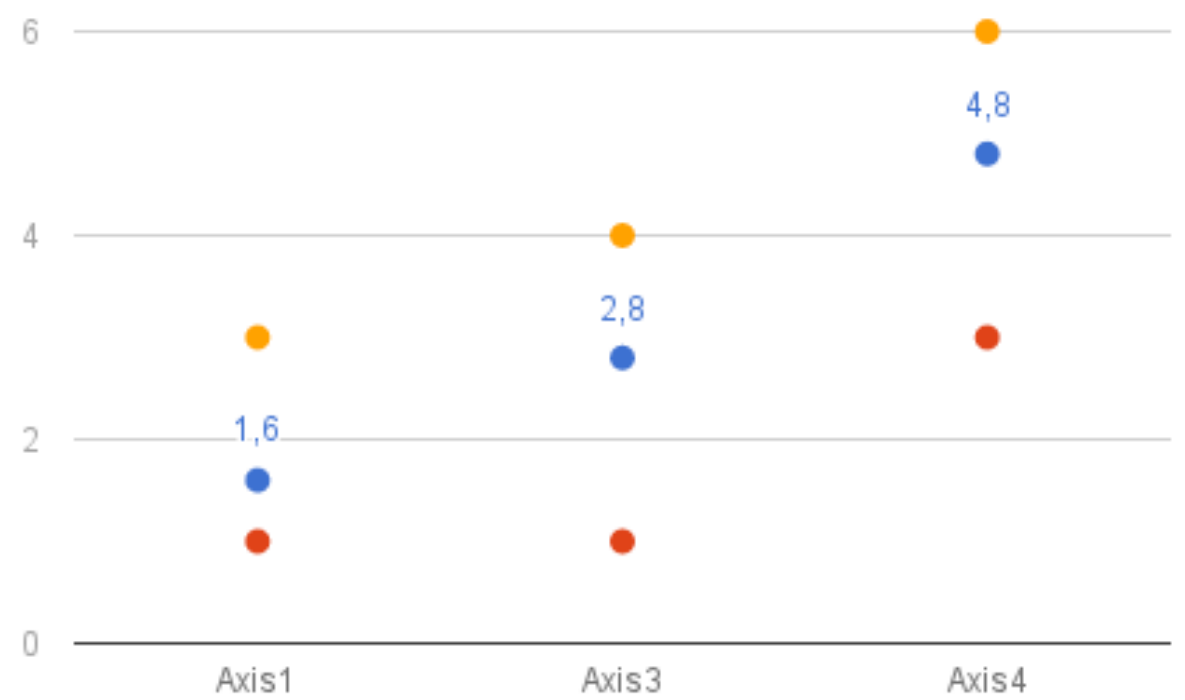

Source: Calculations of the authors

Figure 4. Error margins of social marketing dimensions by axis

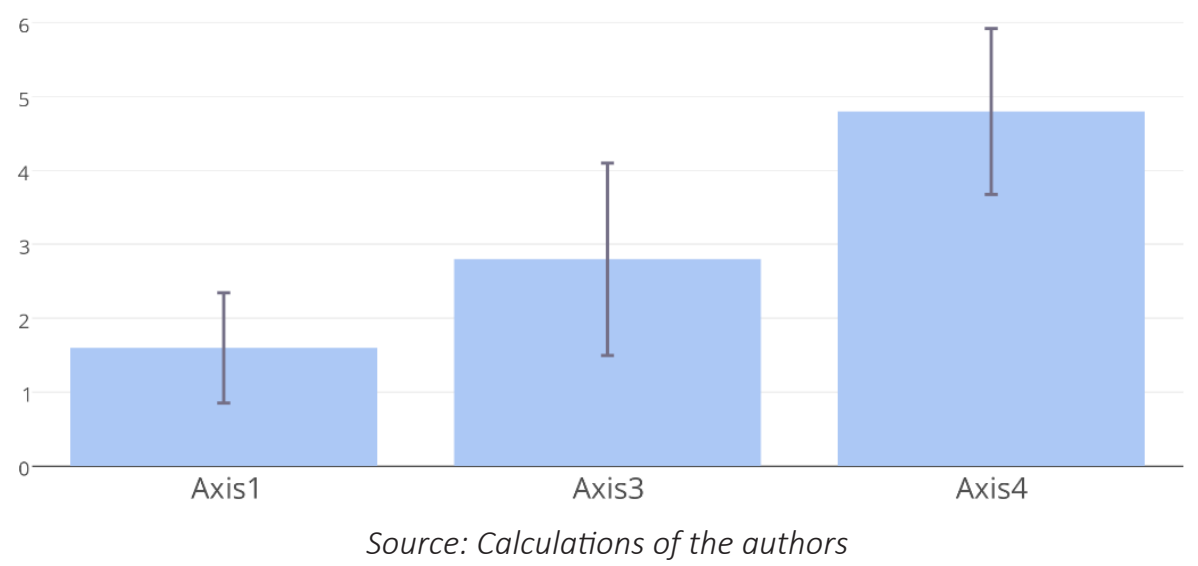

Clearly, LEADER offered the most favourable conditions for social marketing of food. This comes naturalIy from the LEADER approach that strongly valuates networking, collaboration between people, organisations and territories, thus social marketing is its inherent part. In turn, food related projects under the other axes frequently involved investments into infrastructure, machinery, improvements in food processing and ICTs. Especially axes 1 and 3 projects contributed to the creation of new product lines and innovative packaging, enhancing good hygiene and safety standards. In some cases special attention was paid to the compliance with environmental protection standards, sustainability, waste and water management, animal welfare, ecosystem services and biodiversity. However, social marketing was generally much less important than in the LEADER axis. At least one dimension was identified in $28.3 \%$ of the axis 1 food projects, and in $26.3 \%$ food projects under axis 3. Therefore, we can say that social marketing was often visible, but not a strongly embedded approach. 
Overall, the supported projects, as claimed in their project descriptions, resulted in an enhanced quality of food products, contributing to increased access to markets and/or higher returns from sales. Also, the investments stimulated the rise of production capacity and the ability to meet supply demand from larger retailers (e.g. supermarkets). Moreover, many projects involved the creation of direct sales points (e.g. on-farm shops), thus openly strengthening local food supply chains. Food traceability was also an important objective, and the acquisition of the EU geographic indications and organic farming labels was a typical result of successful projects involving social marketing elements. According to the ENRD database both small and large producers participated in such schemes, resulting in better market positions in general.

\section{CONCLUSIONS AND FUTURE RESEARCH OUTLOOK}

Our paper focused on food marketing schemes that are crucial for coping with challenges of the globalising agro-food system. We reviewed the major trends and mechanisms driving food standards, certification and labelling in the EU context, including relevant interplays of markets and public policies. We also provided a survey of the ENRD database on best practice examples of projects supported under the RDPs. Based on contextual analysis of project description we argue that social marketing of food is a significant, tangible strategy for coping with challenges within the agro-food system.

The typology of social marketing was developed, characterised by certain observable activities and processes. It was grouped into six dimensions: (1) Cooperation; (2) Joint marketing; (3) Social events; (4) Social learning; (5) Intercultural learning; and (6) Social space. The number of characteristics applied in individual projects varied greatly, however, it was revealed that successful marketing of food is supported with a holistic and multidimensional approach. Most visibly, social marketing was practiced in the LEADER axis. It was also detectable under axes 1 and 3, whereas it did not concern axis 2 at all. Moreover, in a few selected cases we learnt that social marketing positively contributed to strengthening the market position of the food chain actors. It triggered collective approaches to problem solving in rural communities and increased their internal and/or external collaboration, in order to brand new food products or improve branding and joint marketing of the existing ones. Consequently, this led to shortening value chains, expansion on the markets and higher returns. In addition, some projects contributed to improvements of actors' compliance with the public standards set up at the EU level, namely the geographical indications.

Our study proved that social aspects in food production, marketing, supply and retail are significant. Even under axis 1, that was predominantly intended to support modernisation and investments of food production, social marketing elements supported the implementation of successful projects. Notably, cooperation between stakeholders seems to be crucial for the success of many projects and was clearly visible in the majority of cases we studied. Therefore, these particular mechanisms of social marketing could be more consciously integrated into the various RDP measures, in order to foster a greater impact. As the recent policy discussions revolve around the need to emphasise the 'food policy' in the EU undertakings, we argue that more effort could be invested into exploring the different factors beyond actual success or failure of the food projects that were supported with the EU funding. More account could be taken of the social marketing elements. Possibly, 
an approach could be developed promoting projects that could address the food system challenges in a holistic way, rather than being based on single measures.

Judging by the examples of projects accessible for this study, we argue that social marketing, although not mentioned explicitly, has a prominent place in the EU-funded approaches to support food. Through specialised projects and dedicated activities, it is fostered across the EU. However, as the availability of data is still limited, our findings should be treated as the starting points for further investigations, rather than ultimate statements. The ENRD database proved to be a functional basis for the identification of relevant projects and general trends in their implementation and results. We could make observations on the character of each axis or measure and the supported projects. Nevertheless, the available evidence is not robust enough, nor sufficient to project their long term impacts.

The database does not deliver a clear message on what kind of combination of these six dimensions could result in best practice, or what minimum requirements for supporting food projects need to be fulfilled in order to strengthen the local economy and society. Neither can the connections between social marketing elements and long-term impacts of projects and how these are affected by the social and economic background of the project area be precisely explained. Further in-depth investigations of complex projects with a strong focus on social aspects in marketing strategies is needed. The potential of complementing 'investive' and 'infrastructural' measures with more collective approaches could also be explored further. All this is important to justify public spending on agricultural policies, giving a high priority to food. It can also be crucial to ensure viable support for the participation of rural communities and smallholder food producers in the globalising value chains. 


\section{REFERENCES}

Andreasen, A. R. (1994) Social marketing: Its definition and domain. Journal of public policy and marketing, 108-114. http://dx.doi.org/10.1080/15245004.2000.9961103.

Barjolle, D. - Paus, M. - Petter, A. (2009) Impacts of Geographical Indications: Review of Methods and Empirical Evidences. International Association of Agricultural Economists Conference, August 16-22, Beijing, China.

Barjolle, D. - Sylvander B. (2002) Some Factors of Success for 'Origin Labelled Products' in Agro-Food Supply Chains in Europe: Market, Internal Resources and Institutions. Économies et Sociétés, 25: 1441-1461.

Bock, B. (2013) Social innovation and sustainability: how to disentangle the buzzword and its application in the field of agriculture and rural development. Studies in Agricultural Economics, 114: 57-63. http://dx.doi.org/10.7896/j.1209.

Bryden, J. - Hart, K. (eds) (2004) A new approach to rural development in Europe: Germany, Greece, Scotland, and Sweden. Mellen Studies in Geography.

Busch, L. (2010) Standards, law, and governance. Journal of Rural Social Sciences, 25(3): 56-78.

Castells, M. (1996) The Rise of the Network Society. The Information Age: Economy, Society and Culture Vol. I. Cambridge, MA, Oxford, UK: Blackwell. http://dx.doi.org/10.1002/9781444319514.

Cooley, J. P. - Lass, D. A. (1998) Consumer benefits from community supported agriculture membership. Review of Agricultural Economics, 20(1), 227-237. http://dx.doi.org/10.2307/1349547.

Cone, C., - Myhre, A. (2000) Community-supported agriculture: A sustainable alternative to industrial agriculture? Human organization, 59(2), 187-197. http://dx.doi.org/10.17730/humo.59.2.715203t206g2j153.

Council Regulation (EEC) No 2081/92 of 14 July 1992 on the protection of geographical indications and designations of origin for agricultural products and foodstuffs.

Council Regulation (EC) No 1698/2005 of 20 September 2005 on support for rural development by the European Agricultural Fund for Rural Development.

Council Regulation (EC) No 834/2007of 28 June 2007 on organic production and labelling of organic products.

DOOR Database

http://ec.europa.eu/agriculture/quality/door/list.html?locale=en\&recordSelection=all\&recordStart=0\&filter dossierNumber=\&filter.comboName=\&filterMin.milestone__mask=\&filterMin.milestone=\&filterMax. milestone mask=\&filterMax.milestone=\&filter.country=PL\&filter.category=\&filter.type=\&filter.status= [last accessed July 2015]

European Network for Rural Development, Rural Development Programmes' projects database http://enrd.ec.europa.eu/enrd-static/policy-in-action/rdp_view/en/view_projects_en.html [last accessed July 2015]

Fonte, M. (2002) Food Systems, Consumption Models and Risk Perception in Late Modernity. International Journal of Sociology of Agriculture and Food, 10(1): 13-21. http://dx.doi.org/10.1504/ijtm.1998.002688.

Friedmann, H. (2005) From colonialism to green capitalism: Social movements and emergence of food regimes. Research in rural sociology and development, 11, 227. http://dx.doi.org/10.1016/s1057-1922(05)11009-9.

Glaser, B. S. - Strauss, A. (1967) The discovery of grounded theory. New York.

Goodman, D. (2004) Rural Europe redux? Reflections on alternative agro-food networks and paradigm change. Sociologia ruralis, 44(1), 3-16. http://dx.doi.org/10.1111/j.1467-9523.2004.00258.x.

Gorton, M. - Török, A. - Tregear, A. (2014) The Impact of EU Agri-food Quality Policy in the New Member States: A Case Study of the Makó Onion PDO, 142nd EAAE Seminar Growing Success? Agriculture and rural development in an enlarged EU, 29-30 May, Budapest, Hungary.

Guthman, J. (2008) Bringing good food to others: investigating the subjects of alternative food practice. Cultural geographies, 15(4), 431-447. http://dx.doi.org/10.1177/1474474008094315.

Hatanaka, M. - Bain, C. - Busch, L. (2005) Third-party certification in the global agrifood system. Food Policy, 30(3): 354-369. http://dx.doi.org/10.1016/j.foodpol.2005.05.006

High, C. - Nemes, G. (2007) Social Learning in LEADER: Exogenous, Endogenous and Hybrid Evaluation in Rural Development. Sociologia Ruralis, 47(2): 103-119. http://dx.doi.org/10.1111/j.1467-9523.2007.00430.x.

Ilberry, B. - Kneafsey, M. (1999) Niche markets and regional speciality food products in Europe: towards a research agenda. Environment and Planning A, 31: 2207-2222. http://dx.doi.org/10.1068/a312207.

Knickel, K. - Brunori, G. - Randa, S. - Proost, J. (2009) Towards a Better Conceptual Framework for Innovation Processes in Agriculture and Rural Development: From Linear Models to Systemic Approaches. The Journal of Agricultural Education and Extension, 15(2): 131-146. http://dx.doi.org/10.1080/13892240902909064.

Kotler, P. - Zaltman, G. (1971) Social marketing: an approach to planned social change. The Journal of Marketing, 3-12. http://dx.doi.org/10.2307/1249783. 
Kotler, P. - Roberto, E. L. (1989) Social marketing. Strategies for changing public behavior. Journal of Marketing, 55(1):108. http://dx.doi.org/10.2307/1252208.

Kotler, P. - Roberto, N. - Lee, N. (2002) Social marketing: Improving the quality of life. http://dx.doi.org/10.1093/pubmed/fdg040.

Lefebvre, R. C. - Flora, J. A. (1988) Social marketing and public health intervention. Health Education \& Behavior, 15(3): $299-315$. http://dx.doi.org/10.1177/109019818801500305.

Loconto, A. - Busch, L. (2010) Standards, Techno-Economic Networks, and Playing Fields: Performing the Global Market Economy. Review of International Political Economy, 17(3): 507-536. http://dx.doi.org/10.1080/09692290903319870.

Loconto, A. - Dankers, C. (2014) Impact of international voluntary standards on smallholder market participation in developing countries. FAO-Rome.

Lowe, P. - Murdoch, J. - Ward, N. (1995) Beyond endogenous and exogenous models: Networks in rural development. In J.D. van der Ploeg and G. van Dijk (eds.) Beyond Modernization: The Impact of Endogenous Rural Development. Assen-Netherlands-Van Gorcum, 87-105.

Marescotti, A. (2000) Marketing channels, quality hallmarks and the theory of conventions. In Sylvander, B. - Barjolle, D. - Arfini, F. (eds.) The socio-economics of origin labelled products in agrofood supply chains: spatial, institutional and co-ordination aspects. Serie Actes et Communications, 17(2), INRA - Paris, 103-122.

Marescotti, A. (2003) Typical products and rural development: Who benefits from PDO/PGI recognition?. 83rd EAAE SEMINAR Food Quality Products in the Advent of the 21st Century, Production, Demand and Public Policy, 4-7 September, Chania, Greece.

Marsden, T. - Banks, J. - Bristow, G. (2000) Food supply chain approaches: exploring their role in rural development. Sociologia Ruralis, 40 (4): 424-439. http://dx.doi.org/10.1111/1467-9523.00158.

Michaelis, L. - Lorek, S. (2004) Consumption and the Environment in Europe: Trends and Futures. Copenhagen - Danish Environmental Protection Agency.

Nemes, G. - High, C. - Augustyn, A. (2014) Beyond the New Rural Paradigm: Project state and collective reflexive agency. In Copus, A. - de Lima, P. Territorial Cohesion in Rural Europe: The Relational Turn in Rural Development. Routledge. http://dx.doi.org/10.17649/tet.29.1.2703.

OECD (2006) The new rural paradigm: Policies and Governance. http://dx.doi.org/10.1787/9789264023918-4-en.

Pacciani, A. - Belletti, G. - Marescotti, A. - Scaramuzzi, S. (2001) The role of typical products in fostering rural development and the effects of Regulation (EEC) 2081/92. 73rd Seminar of the European Association of Agricultural Economists, 28-30 June, Ancona, Italy.

Renting, H. - Marsden, T. - Banks, J. (2003) Understanding alternative food networks: exploring the role of short food supply chains in rural development. Environment and Planning A, 35: 393-411. http://dx.doi.org/10.1068/a3510.

Ray, C. (1998) Culture, intellectual property and territorial rural development. Sociologia Ruralis, 38(1): 3-20. http://dx.doi.org/10.1111/1467-9523.00060.

Reisch, L. - Eberle, U. - Lorek, S. (2013) Sustainable food consumption: an overview of contemporary issues and policies. Sustainability: Science, Practice, \& Policy, 9(2), 7-25.

Shucksmith, M. (2010) Disintegrated Rural Development? Neo-endogenous Rural Development, Planning and Place-Shaping in Diffused Power Contexts. Sociologia Ruralis, 50(1), 1-14. http://dx.doi.org/10.1111/j.1467-9523.2009.00497.x.

Tregear, A. - Kuznesof, S. - Moxey, A. (1998) Policy initiatives for regional foods: some insights from consumer research. Food Policy, 23(5): 383-394. http://dx.doi.org/10.1016/s0306-9192(98)00044-x.

Tregear, A. - Arfini , F. - Belletti, G. - Marescotti, A. (2007) Regional foods and rural development: The role of product qualification. Journal of Rural Studies, 23: 12-22. http://dx.doi.org/10.1016/j.jrurstud.2006.09.010. 